tation of his great discovery honours fell thickly upon him. He was president of the Société Française de Physique in 1897 . In 1900 the Royal Society awarded him the Rumford medal. In I9O3 the Nobel prize in physics was awarded to him conjointly with the Curies. In 1907 the National Academy of the United States decreed to him the Burnard medal. In 1907 he was president of the Société nationale d'Agriculture, and the Berlin Academy awarded him the Helmholtz medal. In the same year he was elected vice-president of the French Academy of Sciences, and only in June last he was elected perpetual secretary of the Academy in succession to M. Lapparent. He was a member of many foreign academies, and received honorary doctorates from the Universities of Cambridge, Oxford, Aberdeen, Manchester, and Göttingen. He was a foreign fellow of the Physical Society of London, and an honorary member of the Royal Institution, where, in March, r9o2, he lectured on radio-activity. In NATURE of December 22, 1905 vol. Ixxi., p. I77), in an article of the series Some Scientific Centres, by Mr. J. B. Burle, an account is given of the laboratory of the Musée d'Histoire naturelle, illustrated by a portrait of Becquerel amongst the apparatus used in his researches. Amiable and ever courteous, he was greatly endeared to all who knew him by his frank and sympathetic demeanour. He leaves one son, M. Jean Becquerel, Ingénieur des Ponts et Chaussées, who has already distinguished himself by important investigations on the absorption of light in crystals and other researches, the latest of which promises to elucidate the nature of positive electricity. $\mathrm{He}$ has honourably carried on the family tradition even in having been appointed assistant in the Musée d'Histoire naturelle.

\section{THE DUBLIN MEETING OF THE BRITISH ASSOCIATION.}

THE seventy-eighth annual meeting of the British Association for the Advancement of Science began yesterday, September 2, when Mr. Fråncis Darwin, M.A., LL.D., F.R.S., assumed the presidency and delivered his presidential address in the great hall of the Royal University of Ireland, Earlsfort Terrace, Dublin. More than 2000 members and associates are attending the meeting. In the afternoon of the same day the members met informally at the Dublin Mansion House, where the Lord Mayor, Alderman Gerald O'Reilly, bade them welcome in the name of the city.

The sectional meetings began this morning. They are mostly being held in the various schools of Trinity College, the sole college of Dublin University, which was founded some 300 years ago by Queen Elizabeth. The Educational Science Section meets in the Royal University building, which is shortly to be re-modelled for the accommodation of the new and as yet unnamed university founded by Mr. Birrell's recent Act. Other sections meet in the Royal Irish Academy, the Royal College of Science for Ireland (soon to be provided with new and handsome buildings), the historic Leinster House of the Royal Dublin Society, and the Royal Colleges of Physicians and Surgeons. A service of trams and a volunteer service of motor-cars have been arranged to facilitate the circulation of members among the various sections. The official journal, published every morning at Io, gives a list of papers to be read, and an intersectional telephone service announces the progress made with the reading of the various papers.

The examination hall in Trinity College has been fitted up as a reception-room, with the usual facilities as to postal and telegraphic business. Letters should be addressed to "British Association, Dublin." The names of persons for whom telegrams have been received are written on a blackboard at the post office. There is a liberal provision of writing, smoking, and lounge rooms, and drawing-rooms for ladies. There is an official luncheon-room in the dining hall of Trinity College, and luncheons and teas are obtainable in a marquee in the College Park.

The Royal Dublin Society and the Dublin Chamber of Commerce are offering the use of their rooms to members of the Association, and many of the clubs are giving facilities for temporary membership.

The "Handbook" to the city of Dublin and the surrounding district, prepared for the meeting and printed at the Dublin University Press, is an attractive work the production of which is creditable to the general editors, Prof. Grenville Cole and Mr. Lloyd Praeger. It contains 440 pages, numerous illustrations, and an excellent district map. Its contents deal with the geology, meteorology, botany, and zoology (the latter very fully) of the Dublin district. The history and archæology of Dublin are treated by a subcommittee of experts. A melancholy interest attaches to the sketch of the history of Dublin, by Mr. C. Litton Falkiner, late secretary to the council of the Royal Irish Academy, who lost his life mountainclimbing in Switzerland last month. A special chapter, edited by Prof. G. H. Carpenter, deals with the various scientific and other educational institutions of Dublin, and Prof. Adeney's work on Dublin industries and commerce concludes the volume, which will do much to bring the more exceptional features of the Irish capital before the scientific public in an informing and attractive manner.

\section{E. E. Fournier.}

Inaugural AdDress by Francis Darwin, M.A., Ph.D., LL.D., F.R.S., President of the Association.

BEFORE entering on the subject of my Address, I may be allowed to refer to the loss which the British Association has sustained in the death of Lord Kelvin. $\mathrm{He}$ joined the Association in 1847 , and had been for more than fifty years a familiar figure at our meetings. This is not the occasion to speak of his work in the world or of what he was to his friends, but rather of his influence on those who were personally unknown to him. It seems to me characteristic of him that something of his vigour and of his personal charm was felt far beyond the circle of his intimate associates, and many men and women who never exchanged a word with Lord Kelvin, and are in outer darkness as to his researches, will miss his genial presence and feel themselves the poorer to-day. By the death of Sir John Evans the Association is deprived of another faithful friend. He presided at Toronto in 1897 , and since he joined the Association in I86I had been a regular attendant at our meetings. The absence of his cheerful personality and the loss of his wise counsels will be widely felt.

May I be permitted one other digression before I come to my subject? There has not been a Botanical President of the British Association since the Norwich meeting forty years ago, when Sir Joseph Hooker was in the chair, and in "eloquent and felicitous words" (to quote my father's letter) spoke in defence of the doctrine of evolution. I am sure that every member of this Association will be glad to be reminded that Sir Joseph Hooker is, happily, still working at the subject that his lifelong labours have so greatly advanced, and of which he has long been recognised as the honoured chief and leader.

You will perhaps expect me to give a retrospect of the progress of evolution during the fifty years that have elapsed since July $\mathrm{I}, \mathrm{I} 85^{8}$, when the doctrine of the origin of species by means of natural selection was made known to the world in the words of Mr. Darwin and Mr. Wallace.

No. 2027, VOL. 78] 